\title{
Suomalaisnuorten Viipuri-merkitykset ja -muistot
}

Chloe Wells

Esittelen lektiossani väitöskirjani käsitteellisen viitekehyksen, aineistonkeruu- ja -analyysimenetelmät sekä löydökset ja johtopäätökset, jotka valaisevat Suomessa asuvien nuorten rajakaupunki Viipurille antamia merkityksiä ja muistoja siitä.

Keväällä 2020 koronapandemian alkaessa sain valmiiksi väitöskirjani. Pandemia on osoittanut sekä maantieteen että rajojen keskeisen merkityksen. Keskeisiksi ovat tulleet käsitykset paikasta, esimerkiksi "turvallisista" ja "turvattomista" paikoista, sekä erilaisten henkilökohtaisten, paikallisten, kansallisten ja maailmanlaajuisten tasojen vaikutuksista, joihin kuulumme. Pandemian tuomat rajoitukset ja muutokset, jotka kohdistuivat ennen itsestäänselvyytenä pitämäämme elämäntapaan, elämään täynnä huoletonta rajat ylittävää matkustamista, auttoivat minua myös ymmärtämään paremmin niitä psykologisia vaikutuksia, joita tämänkaltaisella aikajanan rikkoutumisella "aikaan ennen ja jälkeen" voi olla. Tämä on ero, jonka olin pannut merkille niiden suomalaisten tarinoissa, jotka toisen maailmansodan aikana evakuoitiin pysyvästi kodeistaan Viipurista ja joiden side siten "katkaistiin ja erotettiin" kaupungista sodan jälkeen.

Miksi tutkin Viipuria? Viipuri on kaupunki, jonka paikka on vaihtunut muuttuneiden rajojen vuoksi valtiosta toiseen ja joka on esitetty suomalaisissa iltapäivälehdissä sekä muuallakin kulttuurisesti tärkeäksi "menetetyksi suomalaiseksi kaupungiksi”. Viipuri on mielenkiintoinen ja erityinen, mutta ei ainutlaatuinen tapaus. Viipuria voi verrata muihin rajakaupunkeihin, joihin toisen maailmansodan aikaiset uudet rajat vaikuttivat, erityisesti Sortavalaan ja Kaliningradiin Venäjällä sekä Lviviin ja Tšernivtsiin Ukrainassa.

Viipuri oli Suureen Pohjan sotaan saakka osa Ruotsia. Vuoteen 1812 asti se oli osa Venäjää ja vuosina 1812-1917 osa Venäjän keisarikuntaan kuuluvaa autonomista Suomen suuriruhtinaskuntaa. Suomen itsenäistyttyä loppuvuodesta 1917 Viipuri nousi kulttuuriselta merkitykseltään tämän uuden kansallisvaltion "kakkoskaupungiksi". 
Toisen maailmansodan jälkeen uuden rajan seurauksena Viipuri päätyi Neuvostoliiton puolelle. Viipurin suomalaiset asukkaat evakuoitiin pysyvästi jatkosodan lopussa kesällä 1944 ja sijoitettiin asumaan Suomeen. Viipuriin muutti leningradilaisia työläisiä, jotka pystyivät auttamaan sodassa vaurioituneen kaupungin jälleenrakentamisessa. Viipuriin muutti myös talonpoikia Keski-Venäjältä, Valko-Venäjältä ja Ukrainasta. Kaupunki muuttui nopeasti Leningradin alueella sijaitsevaksi neuvostokaupungiksi.

Väitöskirjani on nimeltään "Viipuri on teidän/meidän: Rajakaupungin merkityksiä ja muistoja Suomen nykynuorten keskuudessa". Nimessä "teidän/meidän" korostaa sitä, että alueen "omistajuus" on kaikkea muuta kuin suoraviivaista Viipurin kaltaisella raja-alueella, jolla on pitkä historia kuulumisesta rajan useammille puolille. Ensimmäisenä asuinvuotenani Suomessa vuonna 2011 huomasin otsikon "Viipuri on meidän!" Ilta-Sanomien nelisivuisen artikkelin yllä. Artikkelissa muisteltiin suomalaisjoukkojen jatkosodassa tekemän Viipurin takaisin valtaamisen 70-vuotispäivää. Juuri suomalaisten iltapäivälehtien Viipurista kertovat artikkelit sekä niiden herättämät kommentit ja keskustelut saivat minut kiinnostumaan niistä merkityksistä ja muistoista, jotka liittyvät kyseiseen raja-alueeseen. Paikkaan, joka ei ole ollut osa Suomea yli 75 vuoteen, mutta jota jotkut silti pitävät tärkeänä sille, mitä suomalaisuus on ja - mikä tärkeämpää - paikkana, joka on olennainen suomalaisuuden käsittämiselle.

Ne Viipurin rakennukset, jotka ymmärretään "suomalaisiksi", ovat fyysisesti romahduksen partaalla. Niitä joko kunnostetaan tai puretaan. Uusien rakennusten rakentaminen muuttaa Viipurin katukuvaa. Tällaiset konkreettiset todisteet siitä, että aika kuluu Viipurissa, herättävät suomalaisessa mediassa keskustelua menneisyyden merkityksestä nykyhetkessä. Mediakeskustelut keskittyvät "ongelmaan", jossa "paikka" ilmentää samanaikaisesti sekä soljuvaa aikaa että muuttumatonta tilaa, "ongelmaa" siitä, että alueet ja paikat muuttuvat ajan kuluessa ja poliittisissa hallintomuutoksissa, sekä "ongelmaa", jossa menneisyyden muistojen paikka ei enää vastaa nykyistä todellisuutta.

Viipuriin liitettyjen yleisten merkitysten ja muistojen tutkimuksessa minua kiinnostaa erityisesti se, että muistellessa Suomen aikaista Viipuria tunne paikasta on usein varsin myönteinen. Toisaalta piirtyy myös "kaksiulotteinen", "pysähtynyt" ja "mustavalkoinen" kuva kaupungista ennen toista maailmansotaa. Suomessa asuvien Viipuriin liittyvissä merkityksissä ja muistoissa "meidän" on useimmiten muisto menetetystä suomalaisesta kaupungista, abstrakti paikka, joka rakentuu ikään kuin nykyisen konkreettisen paikan, Venäjän Viipurin, päällikerrokseksi. "Teidän" on Neuvostoliiton ja Venäjän Viipuri, jota verrataan negatiivisesti kuviteltuun "kultaiseen" suomalaiseen aikakauteen. Ajatus siitä, että Viipuri on "teidän tai meidän" viestii sekä paikkaan liittyvien muistojen ja muistin jatkuvuudesta että rikkoutumisesta ja herättää erityisen tunteen paikasta. Väitöskirjassani osoitan, kuinka Viipuri on samanaikaisesti sekä "teidän" että "meidän" merkityksissä ja muistoissa, joihin nykynuoret Suomessa samastuvat ja joita he rekonstruroivat. Asemoin tutkimukseeni osallistuneet Suomessa asuvat nykynuoret "kolmanneksi yhteiskunnalliseksi sukupolveksi" toisen maailmansodan jälkeen. "Ensimmäinen sukupolvi" ovat he, joilla on henkilökohtaisia - usein lapsuusajan - muistoja toisesta maailmansodasta. "Toinen sukupolvi" syntyi sodan jälkeen ja "kolmas sukupolvi", tutkimukseni kohde, on Neuvostoliiton jälkeinen sukupolvi. Seuraavien kahdenkymmenen vuoden kuluessa siirrymme "neljännen" eli "jälkitodistajien" sukupolven aikaan. Tämä sukupolvi syntyy ilman heitä, jotka elivät toisen maailmansodan aikana.

Jotkut saattavat kyseenalaistaa, onko "kolmas sukupolvi" kovin erilainen kuin "toinen", sillä molemmat ovat perineet muistoja Suomen Viipurista, jota he eivät koskaan henkilökoh- 
taisesti kokeneet. Väitän kuitenkin, että "kolmas sukupolvi", nykypäivän Suomessa asuvat nuoret, on oma ryhmänsä. Tutkimukseeni osallistuneet nuoret, jotka ovat syntyneet vuosina 1998-2001, eroavat aiemmista sukupolvista, sillä heillä ei ole lainkaan henkilökohtaisia muistoja Neuvostoliiton olemassaolosta, siitä poliittisesta tilanteesta, joka leimaa ensimmäisen ja toisen sukupolven merkityksiä ja muistoja. Tutkimukseeni osallistunut sukupolvi on perinyt merkityksiä ja muistoja, jotka eivät sovi heidän omiin kokemuksiinsa kasvamisesta Suomessa. Tämän sukupolven edustajille toisen maailmansodan tapahtumat ja neuvostoajan ilmapiiri voivat tuntua kaukaisilta ja merkityksettömiltä.

Miksi on tärkeää tutkia nykynuoria "kokonaisuutena" eikä vain heitä, joilla on sukua tai henkilökohtaisia yhteyksiä Viipuriin? Tämä on tutkimukseni avainkysymys. Vastaus kiinnittyy osittain käsitteelliseen viitekehykseeni. Käytän käsitettä jälkimuisti, joka voidaan parhaiten ymmärtää kollektiivisena muistin siirron muotona, sekä käsitettä nostalgia, joka on kollektiivinen tunne menneisyyteen. "Kolmannen sukupolven" Viipuriin liittämiä merkityksiä ja muistoja ei ole aikaisemmin tutkittu

Viipuri voidaan ymmärtää "raja-alueena" kahdessa eri merkityksessä: se on ollut sekä maantieteellisen sijaintinsa vuoksi historiallisesti kiistanalainen rajaseutu että muistoihin "rajattu" menetetty suomalaiskaupunki. Viipuri sijaitsee Suomenlahdella 140 kilometriä Pietarista luoteeseen ja noin 40 kilometriä Venäjän ja Suomen rajalta. Tämä linnoituskaupunki on "vaihtanut puoltaan" useita kertoja alue- ja rajamuutosten takia sen jälkeen, kun ruotsalaiset joukot perustivat kaupungin linnan noin vuonna 1293.

Yksi työni tavoitteista oli kontribuoida rajatutkimukseen. Väitöskirjani tarkastelee alueellisen rajalinjan pakkosiirron aiheuttamia vaikutuksia sekä muistojen rajanylityspotentiaalia "menetetystä" paikasta. Kysyn siis, voivatko muistot ylittää sukupolvien rajoja. Työni sijoittuu myös rajatutkimuksen ja lapsuudentutkimuksen yhtymäkohtiin tuottaen tietoa siitä, kuinka rajoilla on edelleen merkitystä lapsille ja nuorille.

Väitöskirjani osallistuu myös yhteiskuntamaantieteellisiin keskusteluihin erityisesti edistämällä ymmärrystä siitä, miten ja miksi "menetetyt" paikat, jotka aiemmin ovat olleet yhden kansallisvaltion alueella ja nyt toisen rajojen sisällä, kuvitellaan ja muistetaan eri ryhmien sisällä ja välillä. Työni havainnollistaa "paikan" subjektiivisuutta, josta on pitkään väitelty yhteiskuntamaantieteilijöiden keskuudessa. Yhteiskuntamaantieteellisen tutkimuksen, rajatutkimuksen ja lapsuudentutkimuksen lisäksi hyödynnän käsitteitä ja ideoita muistitutkimuksesta. Työni sijoittuu näiden kaikkien tieteenalojen rajapinnoille.

Yksi tärkeimmistä käsitteistä, joka kehystää työtäni on jälkimuisti. Jälkimuisti viittaa siihen, että myöhempien sukupolvien vastaanottamat muistot eroavat aikalaistodistajien mieleen palauttamista muistoista. Väitöskirjassani tarkastelen tätä "vastaanotettua muistia" ja sitä, kuinka kuuluminen "kolmanteen sukupolveen" muovaa merkityksiä ja muistoja.

Väitän, että nuoret eivät ole passiivisia "hankalien menneisyyksien" tai kollektiivisten muistojen vastaanottajia, vaan he aktiivisesti tulkitsevat ja rakentavat niitä uudelleen. Siksi meidän $\underline{e i}$ tule olettaa, että tutkimukseeni osallistujien tulisi tai että he edes voisivat toistaa identtisiä kopioita henkilökohtaisista, ensikäden muistoista suomalaisesta Viipurista. Kun seuraavat sukupolvet yrittävät ymmärtää ja käsitellä muistoja paikoista, joita he eivät ole koskaan henkilökohtaisesti kokeneet, heidän on täytettävä aukot yhdistelemällä toisen käden kertomuksia omien, yksilöllisten - mutta sosiaalisen vuorovaikutuksen alaisten ja sosiaalisesti jaettujen - kokemusten, mielikuvien ja asemointien kanssa luodakseen uusia jälkimuistin "palasia". 
Toinen väitöstutkimustani kehystävistä pääkäsitteistä on spatiaalinen eli tilallinen sosialisaatio, jolla tarkoitetaan yksilön sosialisaatiota maantieteellisesti rajattuihin yhteisöihin, kuten kansallisvaltioihin tai kaupunkeihin. Spatiaalisen sosialisaation kautta yksilöt ja ryhmät voivat saada tunteen siitä, että tietyt paikat ovat "meidän" tai "teidän", tai siitä, että paikka kuuluu "meille" tai "toisille". Spatiaalista sosialisaatiota tapahtuu usealla tavalla: koulutuksen ja median kautta, sukutarinoista sekä vertaisryhmien rakentamista ymmärryksistä.

Kaksi muuta keskeistä työssä käyttämääni käsitettä ovat nostalgia ja nationalismi. Nostalgian kirjaimellinen merkitys on kivulias kaipuu kotiinpaluusta. Nostalginen henkilö haluaa "mennä kotiin", mutta toisaalta myös "palata takaisin". Nostalgiaan olennaisesti kuuluva ajatus "paluusta" ja nostalgiset muistot "paremmasta paikasta paremmassa ajassa" voidaan helposti liittää kertomuksiin menneestä kansallisesta suuruudesta. Työssäni käsittelen nostalgian käsitettä kriittisestä näkökulmasta, erityisesti nationalismiin yhdistettynä.

Väitöstutkimukseni ensisijainen itse keräämäni aineisto koostuu 38 tekemästäni fokusryhmähaastattelusta, joihin osallistui yhteensä 325 nuorta 11 eri kaupungista eri puolilta Suomea. Olen vilpittömän kiitollinen fokusryhmiin vapaaehtoisesti osallistuneille lukiolaisille, jotka osoittivat itseluottamusta, innokkuutta ja huumorintajua - jopa pimeinä talviaamuina. Aineistonkeruun lopettaminen oli vaikeaa, erityisesti kun eräs rovaniemeläinen opettaja pohjoiselta napapiiriltä kysyi, olinko ajatellut "vierailla koulussa Pohjois-Suomessa!". Matkustaessani toteuttaakseni fokusryhmähaastatteluita opin epäilemättä paljon uudesta kotimaastani.

Haastatellut nuoret näkivät minut todennäköisesti "kolminkertaisesti ulkopuolisena": olin heitä vanhempi, ulkomaalainen ja tutkija. Oma asemani on ollut tärkeä osa tutkimusmetodologiaani. "Ulkopuolisena" pystyin käsittelemään Viipuria esittäen "naiiveja kysymyksiä".

Tavoitteeni ei ollut arvioida tutkimukseeni osallistuvieni historian tai maantieteen tietämystä tai kouluoppimista. Fokusryhmäkeskustelut perustuivat siihen, että en "testaa" osallistujiani tai tuomitse heidän vastauksiaan. Sen sijaan annoin niihin osallistujille "ehdottoman myönteisen arvostukseni". Olin - ja olen edelleen - kiinnostunein siitä, kuinka fokusryhmiin osallistuneet rakensivat ja keskustelivat merkityksistä ja muistoista sekä tarkastelivat tiettyjä teemoja.

Fokusryhmäaineiston lisäksi analysoin 13 entisten viipurilaisten kirjoittamaa henkilökohtaista muistokertomusta, jotka oli julkaistu iltapäivälehden erikoisnumerossa vuonna 2013. Lehden tarinat on kerrottu iäkkäiden ihmisten näkökulmasta muistellen heidän kauan sitten tapahtuneita lapsuutensa ja nuoruutensa tapahtumia. Vetämissäni fokusryhmäkeskusteluissa käytettiin kolmea näistä tarinoista ja tarinat julkaisseita lehtien erikoisnumeroita aiheeseen herättelevänä materiaalina.

Fokusryhmien aikana osallistujat tarkastelivat kahta suomalaisajan Viipurista kertovaa erikoislehteä, joissa esitettiin narratiivi "täydellisestä suomalaisesta ennen, tuhotusta venäläisestä jälkeen”. Osallistujat kertoivat myös muista lähteistä, joista he saattaisivat saada tietoa Viipurista. Näitä olivat muun muassa oppikirjat, elokuvat ja perheenjäsenet, mutta vain seitsemän prosenttia osallistujista oli käynyt Viipurissa. Suurimmalla osalla tutkimukseeni osallistuneista ei siis ollut lainkaan kokemusta todellisesta paikasta.

Vertailemalla näitä kahta aineistokokonaisuutta - lehtien aineisto ja tarinat Viipurissa asuneiden muistoista sekä fokusryhmistä saatu aineisto - tulee ilmi yhtäläisyyksiä ja eroavaisuuksia Viipurin muistoista ja merkityksistä eri sukupolvien välillä.

Fokusryhmiin osallistuneet nuoret kokivat Viipurista koetut muistot ja merkitykset toisaalta läheisiksi, toisaalta kaukaisiksi niin ajallisesti kuin maantieteellisesti. Havaitut erot ovat luontaisia jälkimuistin synnyttämille ymmärryksille, joita voi esiintyä ainoastaan 
"myöhemmin" tai tapahtuman ja sen muistelun "jälkeen". Kaiken kaikkiaan tutkimustulokseni nostavat esiin "sukupolvien välisen kuilun", jossa tämän päivän Suomen nykynuoret - joitakin poikkeuksia lukuun ottamatta - erkaantuvat "ikääntyneiden" Viipuriin liittämistä, usein tunnepitoisesti latautuneista merkityksistä ja muistoista. Tutkimukseeni osallistuneet nuoret osoittivat torjuvansa Viipurin menetykseen liittyviä "vaikeita" tunteita. He kuitenkin myös toisentivat Suomessa vakiintunutta narratiivia siitä, että Viipurin toisen maailmansodan jälkeinen historia on "rappeutunut". Tämänkaltainen narratiivi siis näyttää siirtyneen eteenpäin sukupolvelta toiselle.

Väitöstutkimukseni tuottaa tietoa siitä, kuinka Suomessa asuvat nykynuoret ymmärtävät "menetetyn" Viipurin "omistajuuden", ja sen, minne Viipuri "kuuluu" heidän yksilö- ja ryhmätason spatiaalisissa käsityksissään. Koska keskityin tämän päivän lukiolaisiin Suomessa, työni osoittaa tietä myös mahdollisille "tuleville muistoille" Viipurista - kuinka tämä paikka mahdollisesti tullaan muistamaan 2000-luvun Suomessa.

Olen väitöstutkimuksessani nostanut esiin paikan, muistojen ja nationalismin välisiä olenaisen tärkeitä kytköksiä. Minulle tämän työn keskeinen lopputulema on, että nuorten käsitykset tulee sisällyttää näitä kytköksiä koskeviin laajempiin diskursseihin. Olen tutkinut paikkamuistia tietyssä kansallisessa kontekstissa ja näin päässyt tutkimaan "yksilön ja kollektiivisen muistin, kansalaisen ja valtion sekä ajan ja paikan välistä suhdetta" (Hodgkin \& Radstone 2003, 169-170).Väitöskirjassani esittämäni empiirisen tutkimuksen pyrkimyksenä oli avata uusia näkökulmia "kolmannen sukupolven" jälkimuistista paikan suhteen, nykynuorten hyväksymistä tai kieltämistä kansallistetuista historiallista narratiiveista, merkityksistä ja muistoista sekä Viipurin (idealisoidusta) kuvasta ensimmäisen, toisen ja kolmannen sukupolven muistelutyössä.

\section{Englannista suomentaneet Marleena Hyypiä ja Mika Karjalainen}

\section{Lähteet}

Hodgkin, Katharine \& Radstone, Susannah (2003), Part III Patterning the national past. Introduction. - Contested Pasts. The Politics of Memory. Toim. Katharine Hodgkin \& Susannah Radstone. London: Routledge, 169-174.

Wells, Chloe (2020), Vyborg is Y/ours: Meanings and memories of a borderland city amongst young people in Finland [Viipuri on teidän/meidän: Rajakaupungin merkityksiä ja muistoja Suomen nykynuorten keskuudessa]. Väitöskirja. Itä-Suomen yliopisto. http://urn.fi/URN:ISBN:978-952-61-3581-6

YTM Chloe Wellsin yhteiskuntamaantieteen alaan kuuluvan väitöskirja Vyborg is Y/ ours: Meanings and memories of a borderland city amongst young people in Finland tarkastettiin perjantaina 13.11.2020 klo 12 Itä-Suomen yliopiston yhteiskuntatieteiden ja kauppatieteiden tiedekunnassa. Vastaväittäjänä toimi professori Anna-Kaisa Kuusisto (Tampereen yliopisto) ja kustoksena dosentti Paul Fryer (Itä-Suomen yliopisto). 